\title{
Foliar Boron and Nickel Applications Reduce Water-stage Fruit-split of Pecan
}

\author{
M. Lenny Wells ${ }^{1}$ \\ University of Georgia, Department of Horticulture, 4604 Research Way, \\ Tifton, GA 31794
}

Bruce W. Wood

U.S. Department of Agriculture, Agricultural Research Service, SE Fruit and Tree Nut Research Laboratory, Byron, GA 31008-0087

Additional index words. Carya illinoinensis, foliar fertilization, micronutrients, fruit drop, nuclear endosperm, yield

\begin{abstract}
Water-stage fruit-split (WSFS) is a relatively common and often major problem of certain pecan [Carya illinoinensis (Wangenh.) K. Koch] cultivars. This study evaluates the possibility that the malady can be influenced by improving tree micronutrient nutrition. Foliar sprays of boron (B) and nickel (Ni) to WSFS-susceptible fruit of 'Cape Fear' and 'Sumner' are evaluated based on the possibility that either B or Ni potentially affects the severity of WSFS exhibited by trees. Although the incidence of WSFS on 'Cape Fear' was unaffected by micronutrient sprays, the severity of WSFS was substantially reduced in each of the 3 study years by foliar B application and in 2005 by foliar $\mathrm{Ni}$ application. Repeated foliar sprays of Ni also reduced WSFS of 'Sumner' fruit. These data indicate that improving either $\mathrm{B}$ or $\mathrm{Ni}$ nutrition can potentially reduce crop loss resulting from WSFS in certain orchard situations and provides evidence that insufficient availability of $\mathrm{B}$ or $\mathrm{Ni}$ to developing ovary tissues potentially predisposes developing fruit to WSFS when environmental triggers occur.
\end{abstract}

Water-stage fruit-split (WSFS) of pecan is often a major problem exhibited by thinshelled pecan [Carya illinoinensis (Wangenh.) K. Koch] cultivars (e.g., 'Schley', 'Oconee', 'Sumner', 'Wichita', 'Frotcher', and 'Farley') and, to a lesser degree, by certain relatively thick-shelled cultivars (e.g., 'Cape Fear' and 'Elliott'). The malady occurs when the ovary wall (shell), underlying testa (seedcoat), and sometimes the involucre (shuck) splits about the time of the initiation of kernel (cotyledon) filling and shell hardening, resulting in abortion and drop of damaged fruit $\approx 7 \mathrm{~d}$ after splitting (Wood and Reilly, 1999).

The WSFS malady is highly erratic with incidence and severity varying depending on cultivar, location, and year (Prussia et al., 1985). Crop loss can be severe in certain years (Storey, 1969; Worley and Taylor, 1972) and nearly absent in others. Similar fruit-splitting disorders occur on other crops such as apple (Malus domestica Borkh.; Goode et al., 1975), cherry (Prunus avium L.; Verner and Blodgett, 1931), and plum (Prunus domestica L.; Mrozek and Burkhardt, 1973), but they appear to be largely associated with fruit flesh rather than with seed. In the case of pecan, WSFS occurs during the "late water stage," a time when

Received for publication 19 Feb. 2008. Accepted for publication $24 \mathrm{Apr} .2008$.

${ }^{1}$ To whom reprint requests should be addressed; e-maillwells@uga.edu turgor pressure of the liquid endosperm is high (Prussia et al., 1985) and the shell is beginning to become rigid (Allison et al., 1987) with lignin deposition. This typically occurs during mid-August for susceptible cultivars growing in the southeastern United States.

The malady is typically associated with rainfall occurring at the initiation of shell hardening (Storey, 1969). Wood and Reilly (1999) identified two episodes of WSFS for 'Wichita' pecan, the major episode being triggered by increased water availability resulting from rainfall (or potentially irrigation) and potentially a relatively minor event triggered by "high humidity/low light". They also noted that a variety of cultural (e.g., irrigation scheduling and amounts), environmental factors (e.g., rainfall, relative humidity, sunlight/shading, soil characteristics), and tree characteristics (crop load and distribution, nutrient element status) potentially influence WSFS (Wood and Reilly, 1999).

The endosperm of pecan fruit develops from the central cell of the megagametophyte after fertilization by the second nuclear sperm cell migrating from the pollen grain. This triploid nuclear endosperm is located in the proximal zone of a cytoplasm that encompasses a large central vacuole (i.e., endosperm coenocyte) that is filled with a pressurized aqueous solution comprised primarily of elemental ions and sugars (Olsen, 2001).

Turgor pressure generated by solutes forces the testa into the void generated as a result of ovary wall expansion as the fruit grows. This solution-filled central vacuole is present from soon after fertilization until about the time of shell hardening, when acceleration of centripetal growth of alveolus cell layers begins to completely fill the central vacuole to form the cotyledons, but is not particularly noticeable until within a couple weeks before the initiation of shell hardening. It is usually about the time of the formation of radial microtubular systems to deposition of a couple layers of alveroli that WSFS occurs (B.W. Wood, personal observation). Control of turgor pressure exerted by the central vacuole of the nuclear endosperm against the various fruit tissues is at least partially through movement of potassium $\left(\mathrm{K}^{+}\right)$in and out of the endosperm solution. The movement of $\mathrm{K}^{+}$is potentially influenced by several factors, one apparently being the availability of boron (B) within cellular membranes (Parr and Loughman, 1983; Schon et al., 1991). Thus, inadequate B within certain cells and tissues of the developing fruit potentially affects WSFS through its effect on rapid influx or efflux of $\mathrm{K}^{+}$.

Foliar-applied B has been previously shown to increase fruit retention and fruit quality in a number of perennial tree fruit crops, including pecan (Wells et al., 2008). A common aspect of B-deficient plants is brittle cell walls with supraoptimal B concentrations enabling greatly enhanced elasticity (Blevins and Lukaszewski, 1998). Foliarapplied B appears to be highly mobile in some tree species (Picchioni et al., 1995). Thus, timely application of foliar B may potentially influence cell wall elasticity of fruit tissues.

Other potential nutritional factors affecting WSFS include the essential trace micronutrients that link either indirectly or directly to lignification [manganese $(\mathrm{Mn})$, iron $(\mathrm{Fe})$, zinc $(\mathrm{Zn})$, copper $(\mathrm{Cu})$, and nickel $(\mathrm{Ni})]$. Because xylem connections to developing fruit either are absent or poorly formed, their availability to the developing seed is primarily dependent on phloem transport. Certain micronutrients are only variably mobilized in the phloem [Fe, $\mathrm{Zn}, \mathrm{Cu}$, molybenum (Mo), $\mathrm{Ni}$, and cobalt (Co)], whereas others are only conditionally mobile [calcium $(\mathrm{Ca}), \mathrm{B}$, and $\mathrm{Mn}$; Welch, 1999]. Poor plant Ni nutrition potentially affects primary metabolism in such a way that endogenous availability of certain amino acids, organic acids, and acetyl-CoA can potentially limit lignification (Bai et al., 2006), and pecan trees in the southeastern United States can exhibit an early-season Ni deficiency (Wood et al., $2004 a, 2004 b, 2004 c)$. The nature of the interaction between micronutrients and WSFS is unknown, especially for B and $\mathrm{Ni}$.

Crop loss to WSFS is minimized, but not totally prevented, by managing tree water relations to minimize the severity and duration of water stress during the last 2 weeks of fruit sizing and by crop-load thinning. The notion of incorporating a micronutrient component to WSFS management has not been studied. We report here the influence of foliar 
micronutrient sprays of $\mathrm{B}$ and $\mathrm{Ni}$ on WSFS of pecan.

\section{Materials and Methods}

Elemental composition of liquid endosperm. Liquid endosperm was collected in mid-Aug. 2004 from 'Wichita' fruit within the same fruiting cluster as WSFS fruit on the day the WSFS occurred. Developing fruit were surgically excised to expose the nonruptured seedcoat, at which time a hypodermic syringe was used to penetrate the liquid endosperm and the aqueous solution withdrawn and stored until analysis. Samples from six fruit were bulked for analysis. Elemental analysis was by the University of Georgia Plant and Tissue Analysis Laboratory using standard techniques for water analysis.

Influence of boron, nickel, and boron + nickel on water-stage fruit-split-'Cape Fear'. The hypothesis that timely fertilization with either $\mathrm{B}$ or $\mathrm{Ni}$ can reduce WSFS in relatively thick-shelled cultivars was tested on 'Cape Fear'. Studies were conducted in a 20-year-old commercial 'Cape Fear' pecan orchard in Berrien County, GA, growing on a Tifton loamy sand (fine-loamy, silicieous, thermic Plinthic Paleudult) soil. The study spanned over 3 years. Orchard trees were spaced $18.3 \times 18.3 \mathrm{~m}$ and were drip-irrigated as needed throughout the growing season. Treated trees did not exhibit any visible symptoms of B or Ni deficiency, and midsummer leaf concentrations were within the visible symptom-based sufficiency range for pecan [i.e., 15 to $50 \mathrm{mg} \cdot \mathrm{kg}^{-1}$ for B (Plank, 1988) and greater than $\approx 1 \mathrm{mg} \cdot \mathrm{kg}^{-1}$ for $\mathrm{Ni}$ ) ] (Nyczepir et al., 2006). The experiment consisted of three treatments structured as a randomized complete block. Each block was comprised of five trees per experimental unit. There were three blocks in the 2005 study and four blocks in the 2006 to 2007 study. The five sample trees for each treatment were randomly selected from within an orchard row with treated rows being separated by unsprayed border rows. All data are presented as the mean response of the five sampled trees per plot. Treated trees received annual foliar B and Ni treatments. Data were analyzed by analysis of variance for each individual year with mean separation by Fisher's protected least significant difference. Treatments consisted of Top Side Liquid Boron (Triangle Chemical, Macon, GA), a commercial product containing $6 \% \mathrm{~B}$ from tetraboric acid $\left(\mathrm{H}_{2} \mathrm{~B}_{4} \mathrm{O}_{7}\right)$ applied at a concentration of $84 \mathrm{mg} \cdot \mathrm{L}^{-1}$ actual $\mathrm{B}$ as an aqueous spray. The Ni treatment was Nickel Plus (NIPAN, LLC., Valdosta, GA), a commercial product containing $6 \% \mathrm{Ni}$ as $\mathrm{Ni}$ liganosulfonate. Ni was applied at a concentration of $84 \mathrm{mg} \cdot \mathrm{L}^{-1} \mathrm{Ni}$ in water as described for B. An additional treatment in 2005 included a combined mixture of $\mathrm{B}$ and $\mathrm{Ni}$ as described previously. All treatments were compared with an untreated control. Applications were made with a commercial air blast sprayer delivering 935 L spray solution per hectare. Boron treatments were applied before pistil receptivity $(\approx 3$ weeks before anthesis) [stem elongation stage 31, 39/60; flowering stage 69 ; fruit stages $72,-75$ (Finn et al., 2007)] and continued every $14 \mathrm{~d}$ for a total of five applications. Nickel applications were applied at parachute stage in midApril and again $60 \mathrm{~d}$ later. The combined $\mathrm{B}$ and $\mathrm{Ni}$ applications were as described for $\mathrm{B}$ and $\mathrm{Ni}$.

The impact of B and Ni treatments on WSFS was assessed by estimating crop load and the "incidence" and "severity" of WSFS. Crop load was estimated by counting 25 random terminals per tree on five trees within each plot and dividing the number of fruiting terminals by the total number of terminals counted per tree. Incidence is defined as the percentage of clusters with one or more WSFS nuts. Severity is defined as the percentage of WSFS nuts per cluster. For 2005 incidence and severity estimates, fruiting terminals on 20 random terminal shoots per tree, with 10 on each of the east and west sides (20 total branches) of the canopy, were flagged for each of the five data trees in each plot. All counts were made in early August (fruit stage $\approx 79$ ). Incidence of WSFS was estimated by counting the number of flagged clusters with WSFS nuts and dividing by the total number of clusters counted. Severity of WSFS was estimated by counting the number of WSFS nuts per cluster and dividing by the total number of nuts within the cluster. In 2006 and 2007, all WSFS nuts on the ground beneath the tree canopy in a $12.4-\mathrm{m}^{2}$ area were counted. A WSFS severity index rating was estimated by dividing the number of split nuts per tree by the percentage of fruiting terminals. All data are presented as the mean of the five sampled trees per plot.

Foliage was sampled in late July (leaf development stage 19) by collecting eight leaflet pairs from each of the five data trees per treatment per block. All leaflet samples were taken from the middle leaf of sun exposed terminals. Leaflets from all five data trees within a plot were pooled for the sample. Leaflet samples were washed in a dilute phosphate-free detergent solution ( $0.1 \%$ detergent) followed by rinsing with deionized water. Leaves were then dried to a constant weight at $80{ }^{\circ} \mathrm{C}$ and ground in a Wiley Mill (Wiley, Philadelphia, PA) to pass a 1-mm screen. Boron and Ni were measured by an inductive coupled plasma spectrophotometer coupled to a Digiblock 3000 (SCP Science, Baie D’Urfé, Quebec, Canada).

At maturity, a sample of 10 nuts from each of the five data trees in each plot were harvested by hand at midcanopy height directly from the tree following shuck dehiscence but before falling from the tree. Nuts were pooled by plot for each treatment, dried for $21 \mathrm{~d}$, weighed, cracked, and shelled by hand to determine weight per nut and percent kernel. All data were analyzed by analysis of variance (ANOVA) and means were separated using Fisher's protected least significant difference $(P<0.05)$.
Influence of nickel on water-stage fruitsplit-'Sumner'. The hypothesis that timely fertilization with $\mathrm{Ni}$ can reduce WSFS in a relatively thin-shelled cultivar was tested on 'Sumner'. Studies were conducted in a 7year-old commercial-like 'Sumner' orchard in Peach County, GA (latitude 32 $39^{\prime} 54^{\prime \prime} \mathrm{N}$, longitude $83^{\circ} 44^{\prime} 31^{\prime \prime} \mathrm{W}$ ) growing on a Faceville fine sandy loam (fine, kaolintic, thermic Typic Kandiudult) soil. The study was performed in 2006. Orchard trees were spaced $4.6 \times 9.2 \mathrm{~m}$ and were drip-irrigated as needed throughout the growing season. Treated trees did not exhibit visible symptoms of $\mathrm{Ni}$ deficiency, and midsummer leaf concentrations were within the visible symptom-based sufficiency range for pecan (i.e., greater than $\approx 1 \mathrm{mg} \cdot \mathrm{kg}^{-1}$ for $\mathrm{Ni}$ ) (Nyczepir et al., 2006). The experiment consisted of two treatments structured as a randomized complete block. Each block was comprised of two treatments with one tree per experimental unit. There were 16 blocks with trees blocked by both tree diameter and estimated crop load. Data were analyzed by ANOVA. Blocks were within one of 16 tree rows comprised of 48 trees with a border row between treatment rows. Because it was necessary to begin treatment of trees during the canopy expansion phase [stem elongation stage 31, 35/60; flowering stage 69 (Finn et al., 2007)], before crop load could be accurately estimated, all 48 trees per block were treated for all three Ni sprays. During early August, before onset of WSFS, treated and nontreated trees were identified and assigned to block based on trunk caliper and crop load. Treatments consisted of Ni as Nickel Plus (NIPAN, LLC.), a commercial product containing $6 \% \mathrm{Ni}$ as $\mathrm{Ni}$ liganosulfonate. Ni was applied at a concentration of $84 \mathrm{mg} \cdot \mathrm{L}^{-1}$ (NiPlus at $1169 \mathrm{~mL} \cdot \mathrm{ha}^{-1}$ ) in water and an nonionic surfactant $(0.05 \%$ BioSurf). Ni was applied with an air-blast sprayer with the first application going on 15 Apr., with a second being applied $14 \mathrm{~d}$ later, and a third $14 \mathrm{~d}$ after the second application for a total of three applications during the canopy expansion phase of growth. All treatments were compared with a nontreated control. Applications were made with a commercial air-blast sprayer delivering $831 \mathrm{~L}$ spray solution per hectare. WSFS occurred $\approx 16$ Aug. at fruit development stage 79 (Finn et al., 2007). The proportion of fruit exhibiting WSFS was determined in early September by counting all WSFS fruit on the ground beneath the tree canopy and dividing by the total number of fruit retained by the tree. Thus, counting all fruit and blocking by both tree trunk diameter and crop load provided relatively high resolution of treatment effects.

\section{Results}

Elemental composition of liquid endosperm. The liquid endosperm of developing 'Wichita' fruit at time of WSFS contained several elements in solution (Table 1). The concentrations of elements was such that $\mathrm{K}>\mathrm{Ca}>\mathrm{Mg}>\mathrm{P}>\mathrm{Zn}>\mathrm{Cu}>\mathrm{Mn}>\mathrm{Fe}>\mathrm{B}>$ $\mathrm{Na}>$ aluminum $>\mathrm{Ni} \approx$ (cadmium, chromium, 
and Mo). Of the elements analyzed, $\mathrm{K}$ was the primary component with this monovalent cation comprising $\approx 69.4 \%$ of the liquid endosperms elemental components. There was also a substantial concentration of the divalent cations, $\mathrm{Ca}(18.7 \%)$ and $\mathrm{Mg}(8.2 \%)$; hence, $\approx 96.3 \%$ of the elemental composition of the liquid endosperm was made up of three alkali or alkaline-earth metals (i.e., $\mathrm{K}, \mathrm{Ca}$, magnesium).

Influence of boron, nickel, and boron + nickel on water-stage fruit-split-'Cape Fear'. There were no differences in crop load between treatments $(P \leq 0.05)$ in any year of the study (Tables 2 and 3). Micronutrient sprays did not affect weight per nut or percent kernel in any year of the study (data excluded). The "incidence" of WSFS was unaffected by micronutrient sprays (Table 2); however, B and Ni applications alone reduced the severity of WSFS in 2005 ( $P \leq$ 0.05) (Table 2). Foliar B treatments substantially reduced the severity of WSFS in both 2006 and 2007 (Table 3). The B-associated 2006 reduction in WSFS was such that WSFS was only $61 \%$ that of the untreated control, whereas in 2007 , the B treatment was $59 \%$ that of the untreated control. Ni did not reduce severity of WSFS in either 2006 or 2007.

Influence of nickel on water-stage fruitsplit- 'Sumner'. Treatment of 'Sumner', a relatively thin-shelled cultivar, with three early-season foliar sprays of $\mathrm{Ni}$ resulted in a reduction $(P<0.01)$ in the proportion of fruit exhibiting WSFS in 2006 (Table 4).

Table 1. Elemental composition of the liquid endosperm solution from developing 'Wichita' pecan fruit at time of water-stage fruit-split (WSFS) during mid-Aug. 2004.

\begin{tabular}{lcc}
\hline Element & $\begin{array}{c}\text { Concn } \\
\left(\mathrm{mg} \cdot \mathrm{L}^{-1}\right)\end{array}$ & $\begin{array}{c}\text { Relative } \\
\text { composition (\%) }\end{array}$ \\
\hline Aluminum & 0.07 & $<0.01$ \\
Boron & 0.33 & 0.01 \\
Cadmium & $<0.005$ & $<0.01$ \\
Calcium & 578.6 & 18.7 \\
Chromium & $<0.005$ & $<0.01$ \\
Copper & 0.89 & 0.29 \\
Iron & 0.40 & 0.01 \\
Magnesium & 252.6 & 8.2 \\
Manganese & 0.41 & 0.01 \\
Molybdenum & $<0.005$ & $<0.01$ \\
Nickel & $<0.005$ & $<0.01$ \\
Phosphorous & 111.5 & 3.6 \\
Potassium & 2142.0 & 69.4 \\
Sodium & 0.10 & $<0.01$ \\
Zinc & 1.35 & 0.04 \\
\hline
\end{tabular}

Table 2. Crop load (percentage of fruiting terminals) and effect of micronutrient sprays on water-stage fruit-split (WSFS) incidence (percentage of fruiting terminals exhibiting WSFS) and severity (percentage of WSFS nuts per cluster) on 'Cape Fear' pecan in 2005.

\begin{tabular}{lccc}
\hline Treatment & $\begin{array}{c}\text { Crop load } \\
\text { (\% fruiting terminals) }\end{array}$ & WSFS incidence (\%) & WSFS severity (\%) \\
\hline Untreated & $60 \mathrm{a}^{\mathrm{z}}$ & $33.6 \mathrm{a}$ & $42.1 \mathrm{a}$ \\
Boron & $60 \mathrm{a}$ & $22.0 \mathrm{a}$ & $24.0 \mathrm{~b}$ \\
Nickel & $59 \mathrm{a}$ & $26.2 \mathrm{a}$ & $26.9 \mathrm{~b}$ \\
Boron + nickel & $58 \mathrm{a}$ & $25.3 \mathrm{a}$ & $31.0 \mathrm{ab}$ \\
\hline
\end{tabular}

${ }^{\mathrm{z}}$ Means followed by different letters are different at $P=0.05$ through analysis of variance testing.

Untreated trees had $43 \%$ of their crop exhibiting WSFS, which is a substantial percentage of the crop. Conversely, treatment with $\mathrm{Ni}$ reduced WSFS to $34 \%$ of the crop. Thus, $\mathrm{Ni}$ use reduced WSFS crop loss to $79 \%$ of the control.

\section{Discussion}

These data indicate that the severity of WSFS exhibited by pecan trees partially links to nutrient deficiencies that affect tissues of the developing fruit. Movement of nutrients from the maternal plant to fruit sink tissues is partially controlled by transport through phloem vessels, because no mature xylem vessels extend completely into the ovary's tissues (Welch, 1999). The relatively low transpiration rate of developing fruit and humid conditions of tissues contained within the ovary wall also contribute to little movement of mineral nutrients into ovary tissues. Thus, phloem connections to apoplasmic spaces adjoining the testa, subsequent absorption by testa cells, and movement within the symplasm of testa and nuclear endosperm cells are critical to meeting the needs of the developing nuclear endosperm. A similar situation exists for the developing ovary wall.

The relative abundance of $\mathrm{K}$ in the liquidfilled vacuole of the nuclear endosperm indicates that $\mathrm{K}^{+}$is likely the key factor regulating the turgor pressure exerted by the vacuolar liquid endosperm within the developing pecan fruit; consequently, there must also exist a $\mathrm{K}$-associated pressure-regulating mechanism to prevent excessive turgor pressure from rupturing the vacuole. We therefore postulate that factors affecting the speedy transmembrane-associated influx or efflux of $\mathrm{K}^{+}$are key to predisposing fruit to WSFS. Although $\mathrm{K}^{+}$readily translocates in phloem vessels to developing ovary tissues, $\mathrm{B}$ is only conditionally mobile and $\mathrm{Ni}$ is variably mobile, hence leading to potential deficiency within developing tissues (Welch, 1999).

The observed influence of either $\mathrm{B}$ or $\mathrm{Ni}$ fertilization on severity of WSFS indicates that there is indeed a potential deficiency in either B or Ni sufficient to lead to suboptimal processes involved in the development of certain ovary tissues that predisposes developing fruit to WSFS. This limitation could be the result of low bioavailability in the soil solution, poor root uptake, limitations on phloem loading or phloem sap transport from source to ovary tissues, uploading of sap

HortScience Vol. 43(5) August 2008 nutrients within ovary tissues, or phloemxylem nutrient element exchange processes (Welch, 1999).

Although the incidence of WSFS was unaffected by micronutrient sprays, WSFS severity was reduced for 'Cape Fear', a relatively thick-shelled cultivar, in each of the three study years (2005 to 2007) by foliar B application. Severity of WSFS was also reduced in 2005 on 'Cape Fear', and in 2006 on 'Sumner', by foliar Ni application. The mechanism by which $\mathrm{B}$ and $\mathrm{Ni}$ influence the severity of WSFS is speculative; however, circumstantial evidence pertaining to the observed abundance of $\mathrm{K}$ in liquid endosperm solution, the apparent role of $\mathrm{B}$ in $\mathrm{K}$ transport across membranes (Brown et al., 2002; Parr and Loughman, 1983; Schon et al., 1991), the influence of B on cell wall elasticity (Blevins and Lukaszewski, 1998), and the potential influence of $\mathrm{Ni}$ on lignification (Bai et al., 2006; Wood et al., 2004a) collectively support multiple mechanisms in which these two trace elements can individually influence WSFS. Observations by Picchioni et al. (1995) that foliar-applied B is highly mobile in certain tree fruit species appear to be also true for pecan in that foliar B sprays reduced structural damage to developing fruit long after B was applied to foliage.

Water-stage fruit-split is associated with an interaction between turgor pressure and shell strength (Allison et al., 1987; Prussia et al., 1985; Wood and Reilly, 1999). There is evidence that $\mathrm{B}$ enhances the movement of $\mathrm{K}^{+}$across cell membranes (Brown et al., 2002). Potassium is involved in the water

Table 3. Crop load (percentage of fruiting terminals) and effect of micronutrient sprays on severity rating index ${ }^{z}$ of water-stage fruit-split (WSFS) of 'Cape Fear' pecan in 2006 and 2007'.

\begin{tabular}{llcc}
\hline Yr & Treatment & $\begin{array}{c}\text { Crop load } \\
\text { (\% fruiting } \\
\text { terminals) }\end{array}$ & $\begin{array}{c}\text { WSFS severity } \\
\text { rating (\%) }\end{array}$ \\
\hline 2006 & & & \\
& Untreated & $82 \mathrm{a}$ & $51.6 \mathrm{a}$ \\
& Boron & $74 \mathrm{a}$ & $31.4 \mathrm{~b}$ \\
& Nickel & $77 \mathrm{a}$ & $50.0 \mathrm{a}$ \\
2007 & & & \\
& Untreated & $61 \mathrm{a}$ & $166.8 \mathrm{a}$ \\
& Boron & $73 \mathrm{a}$ & $99.0 \mathrm{~b}$ \\
& Nickel & $67 \mathrm{a}$ & $141.0 \mathrm{a}$ \\
\hline
\end{tabular}

${ }^{\mathrm{z}}$ WSFS severity rating index $=$ number of WSFS nuts per tree/percentage of fruiting terminals. ${ }^{y}$ Means followed by different letters are different at $P=0.05$ through analysis of variance testing.

Table 4. Influence of foliar sprays of nickel (NickelPlus) on water-stage fruit-split (WSFS) of 'Sumner' pecan in $2006^{\mathrm{z}}$.

\begin{tabular}{|c|c|}
\hline Treatment & $\begin{array}{c}\text { Proportion of crop } \\
\text { exhibiting WSFS ( } \% \text { per tree) }\end{array}$ \\
\hline Untreated & $43 \mathrm{a}^{\mathrm{y}}$ \\
\hline Nickel & $34 \mathrm{~b}$ \\
\hline
\end{tabular}

${ }^{\mathrm{z}}$ Trees received three treatments at $1169 \mathrm{~mL} \cdot \mathrm{ha}^{-1}$ (i.e., 1 pint/acre) at 2 -week intervals beginning in mid-April. Trees were blocked based on trunk diameter and size of crop load.

${ }^{y}$ Means followed by different letters are different at $P=0.006$ through analysis of variance testing. 
relations, charge balance, and osmotic pressure within cells and across membranes (Havlin et al., 2005). Therefore, B might potentially exert an indirect influence on the osmotic pressure within plant cells by facilitating movement of $\mathrm{K}^{+}$across the membrane of the vacuole of the nuclear endosperm. Such a relationship might well influence turgor pressure within the pecan fruit in the late water-stage, thus affecting WSFS. Dell and Huang (1997) suggested that when B was limited later in fruit development, symptoms of abnormal fruit growth may be apparent, thus supporting the observation of a B -association to WSFS in pecan. Further evidence is provided in that $\mathrm{B}$ deficiencies have been previously linked to a premature testa staining disorder in avocado (Harkness, 1959) and misshapen, cracked, or bleeding fruit of mango (Ram et al., 1989).

Although crop load did not differ between treatments within years, this factor was incorporated into the severity rating used in 2006 and 2007 to account for its potential effect. The severity of WSFS has previously been shown to increase with increasing crop load (Wood and Reilly, 1999). The increased severity of WSFS in 'Cape Fear' in all treatments during 2007 may have been influenced to a greater extent by environmental conditions at the site than by crop load. Although environmental conditions were not measured at the study site, the 2007 pecan-growing season in Georgia was characterized by early-season drought and plentiful rainfall during late fruit development. Such conditions would enhance the likelihood of WSFS, especially under conditions of a heavy crop load. Wood and Reilly (1999) suggest that dry soil 2 weeks before entering the watersplit stage can enhance WSFS.

Previous studies have suggested that cultural practices such as crop thinning and management of soil moisture can reduce, but not eliminate, the WSFS problem (Allison et al., 1987; Prussia et al., 1985; Storey, 1969; Wood and Reilly, 1999; Worley and Taylor, 1972). Our results indicate that timely foliar application of either B or Ni can potentially reduce the severity of crop loss to WSFS in certain orchard situations and may be useful components of strategies to reduce WSFS losses in commercial orchard enterprises. These observations lead us to postulate that
WSFS in pecan is partially controlled by a timely interplay between $\mathrm{B}$ and $\mathrm{K}$ flux within the nuclear endosperm and the roles of $\mathrm{B}$ and $\mathrm{Ni}$ in lignification of the ovary wall, because these processes interact with sudden changes in the balance of available water from the maternal plant to the vacuole of the nuclear endosperm of the developing fruit. Efforts to reduce crop losses to WSFS might well benefit from strategies to ensure that ovary tissues are well supplied with bioavailable forms of $\mathrm{B}, \mathrm{Ni}, \mathrm{K}$, and perhaps other trace nutrient elements in certain orchard situations.

\section{Literature Cited}

Allison, J.M., S.E. Prussia, J.W. Daniell, and E.W. Tollner. 1987. Measuring the internal pressure of maturing pecans. Trans. Amer. Soc. Agr. Eng. 30:1869-1872.

Bai, C., C.C. Reilly, and B.W. Wood. 2006. Nickel deficiency disrupts metabolism of ureides, amino acids, and organic acids of young pecan foliage. Plant Physiol. 140:433-443.

Blevins, D.G. and K.M. Lukaszewski. 1998. Boron in plant structure and function. Annu. Rev. Plant Physiol. Plant Mol. Biol. 49:481500.

Brown, P.H., N. Bellaloui, M.A. Wimmer, E.S. Bassil, J. Ruiz, H. Hu, H. Pfeffer, F. Dannel, and V. Romheld. 2002. Boron in plant biology. Plant Biol. 4:205-223.

Dell, B. and L. Huang. 1997. Physiological response of plants to low boron. Plant Soil 193:103-120.

Finn, G.A., A.E. Straszewski, and V. Peterson 2007. A general growth stage key for describing trees and woody plants. Ann. Appl. Biol. 151:127-131.

Goode, J.E., M.M. Fuller, and K.J. Hyrcyz. 1975. Skin-cracking of Cox's Orange Pippin apples in relation to water stress. J. Hort. Sci. 50:265269.

Harkness, R.W. 1959. Boron deficiency and alternate bearing in avocados. Proc. Florida State Hort. Soc. 72:311-317.

Havlin, J.L., J.D. Beaton, S.L. Tisdale, and W.L. Nelson. 2005. Soil fertility and fertilizers. Pearson Education Inc., Upper Saddle River, NJ.

Mrozek, R.F. and T.H. Burkhardt. 1973. Factors causing prune side-cracking. Trans. Amer. Soc. Agr. Eng. 16:686-692, 695.

Nyczepir, A.P., B.W. Wood, and C.C. Reilly. 2006. Association of Meloidogyne partityla with nickel deficiency and mouse-ear of pecan. HortScience 41:402-404.
Olsen, O.A. 2001. Endosperm development: Cellularization and cell fate specification. Annu. Rev. Plant Physiol. Plant Mol. Biol. 51:233267.

Parr, A.J. and B.C. Loughman. 1983. Boron and membrane function in plants, p. 87-107. In: Robb, D.A. and W.W. Pierpoint (eds.). Metals and micronutrients: Uptake and utilization by plants. Academic Press, New York.

Picchioni, G.A., S.A. Weinbaum, and P.H. Brown. 1995. Retention and the kinetics of uptake and export of foliage-applied, labeled boron by apple, pear, prune, and sweet cherry leaves. J. Amer. Soc. Hort. Sci. 120:28-35.

Plank, C.O. 1988. Plant analysis handbook for Georgia. Georgia Coop. Ext. Serv., Athens, GA.

Prussia, S.A., D.T. Campbell, E.W. Tollner, and J.W. Daniell. 1985. Apparent modulus of elasticity of maturing pecans. Trans. Amer. Soc. Agr. Eng. 28:1290-1296.

Ram, S., L.D. Bist, and S.C. Sirohi. 1989. Internal fruit necrosis of mango and its control. Acta Hort. 231:805-813.

Schon, M.K., D.G. Blevins, and A. Novacky. 1991. Boron: From cell membranes to soybean branching. Current topics in plant biochemistry and physiology. Proc. of the Plant Biochemistry and Physiology Symposium, University of Missouri, Columbia, MO. 10:230-239.

Storey, J.B. 1969. Research notes. Pecan Quarterly $3: 20$.

Verner, L. and C.J. Blodgett. 1931. Physiological studies of the cracking of sweet cherries. Idaho Agr. Expt. Sta. Bull. 184:1-15.

Welch, R.M. 1999. Importance of seed mineral nutrient reserves in crop growth and development, p. 205-226. In: Rengel, Z. (ed.). Mineral nutrition of crops. Food Products Press, New York, NY.

Wells, M.L., P.J. Conner, J.F. Funderburk, and J.G. Price. 2008. Effects of foliar-applied boron on fruit retention, fruit quality, and tissue boron concentration of pecan. HortScience 27:696699.

Wood, B.W. and C.C. Reilly. 1999. Factors influencing water split of pecan fruit. HortScience 34:215-217.

Wood, B.W., C.C. Reilly, and A.P. Nyczepir. 2004a. Mouse-ear of pecan: A nickel deficiency. HortScience 39:1238-1242.

Wood, B.W., C.C. Reilly, and A.P. Nyczepir. 2004b. Mouse-ear of pecan: II. Influence of nutrient applications. HortScience 39:95100.

Wood, B.W., C.C. Reilly, and A.P. Nyczepir. 2004c. Mouse-ear of pecan: I. Symptomatology and occurrence. HortScience 39:87-94.

Worley, R.E. and G.G. Taylor. 1972. An abnormal nut splitting problem of pecan. HortScience $7: 70-71$. 